\title{
Implikasi Teori Pendidikan Spiritualitas menurut Parker J. Palmer bagi Spiritualitas Pendidik Kristen di Gereja
}

\author{
Merensiana Hale \\ Fakultas Teologi, Universitas Kristen Artha Wacana \\ Korepondensi: merenslao0@gmail.com
}

\begin{abstract}
Abstrak: Pendidikan spiritualitas merupakan kebutuhan dalam gereja. Hal ini menjadi sangat penting untuk diperhatikan sebab dalam proses mendidik ada kecenderungan bahwa pendidik hanya memaksimalkan kognitif dan mengabaikan spiritualitas nara didik. Tulisan ini bertujuan membangun spiritualitas pendidik dalam gereja. Tujuan ini menolong para pendidik dalam melakukan pendidikan spiritualitas di gereja. Metode yang digunakan untuk mencapai tujuan adalah kualitatif deskriptif. Hasilnya pendidik perlu membangun dan merawat spiritualitas Kristen sebagai dasar dalam mendidik naradidik di gereja.
\end{abstract}

Kata kunci: spiritualitas, pendidikan, Parker J. Palmer, pendidik

\begin{abstract}
Spirituality education is a necessity in the church. This becomes very important to note because in the educational process there is a tendency that educators only maximize cognitively and ignore the spirituality of students. This paper aims to build the spirituality of educators in the church. This goal helps educators carry out spirituality education in the church. The method used to achieve the goal is descriptive qualitative. The result is that educators need to build and maintain Christian spirituality as the basis for educating educators in the church.
\end{abstract}

Keywords: spirituality, education, Parker J. Palmer, educator

\section{PENDAHULUAN}

Pendidikan yang dilakukan dalam gereja tentunya bertujuan mendewasakan jemaat. Jemaat yang merupakan nara didik hendaknya mengalami pertumbuhan atau pendewasaan secara spiritual ketika mengalami proses pendidikan iman. Tugas gereja dalam mendidik jemaat merupakan amanat firman Tuhan. Tugas pendidikan jemaat yang diamanatkan tersebut mestinya harus bersifat holistik. Tidak hanya memaksimalkan pengetahuan atau kognitif saja tetapi spiritualitas atau hati peserta didikpun harus dimaksimalkan. Holistik dan keseimbangan tujuan dalam pendidikan di gereja tersebut perlu diperhatikan dengan serius. Spiritualitas merupakan dasar dari pendidikan kristiani.

Hal di atas menjadi perhatian oleh karena dalam pelayanan pendidikan di gereja berdasarkan pengalaman penulis ada kecenderungan bahwa pelayanan pendidikan lebih menekankan pada aspek kognitif. Aspek afektif, dalam hal ini spiritualitas kurang mendapat perhatian. Dampaknya terjadi kesenjangan antara pendidik atau guru, naradidik, dan materi yang disampaikan. Padahal mestinya ketiga hal tersebut dapat terjalin dengan baik dan Kristus menjadi dasarnya. Kesenjangan yang terjadi antara guru, 
nara didik dan materi dalam pengamatan penulis disebabkan pengabaian pendidikan spiritualitas.

Terkait judul tulisan ini maka penulis melakukan telaah beberapa literatur atau tulisan terdahulu yang berhubungan dengan pendidikan spiritualitas. Spiritualitas merupakan hal utama dalam pelayanan pendidikan kristiani maka menurut Wilson, siapapun yang menjadi pelayan atau guru harus berkerja berdasarkan panggilan dan karunia yang diberikan Tuhan kepadanya. ${ }^{1}$ Wilson, melanjutkan bahwa sebagai manusia, seorang guru atau pelayan akan terus bergumul dalam nilai-nilai spiritualitas yang dewasa, sehingga sangat penting bagi guru untuk memperkuat dan menunjukkan spiritualitasnya dalam kehidupan sehari-hari dan pelayanan. Siahaan memberi pikiran dalam tulisannya bahwa pendidikan kristiani sangat penting dan dibutuhkan untuk menumbuhkan spiritualitas dalam konteks budaya populer. ${ }^{2}$ Konteks budaya populer yang tidak bisa dihindari dapat disikapi dengan pendidikan kristiani. Siahaan memanfaatkan pemikiran Beaudoin untuk menghubungkan antara pendidikan kristiani dan spiritualitas. Menyambung diskusi tentang spiritualitas, Setiawan menguraikan dalam tulisannya bahwa hakekat spiritualitas pelayanan Kristus harus dijadikan dasar dalam pelayanan hamba-hamba-Nya masa kini. ${ }^{3}$ Termasuk di dalamnya pelayan atau para guru yang melayani naradidik di gereja.

Naradidik menjadi bagian penting dalam cakupan pendidikan kristiani spiritualitas. Dalam tanggung jawab pendidikan, khususnya di gereja, naradidik dimampukan untuk menjadi dewasa melalui proses pendidikan. Dalam kaitannya dengan pendewasaan iman, Laia melalui tulisannya menawarkan model

${ }^{1}$ Bawamenewi Wilson, "Spiritualitas Seorang Pelayan Tuhan," ERESI: Jurnal Teologi dan Pendidikan Agama Kristen 1, no. 1 (2020): 61-66.

${ }^{2}$ Daniel Syafaat Siahaan, "Pendidikan Kristiani sebagai Instrumen Penyadaran Pentingnya Pertumbuhan Spiritualitas dalam Konteks Budaya Populer," GEMA TEOLOGIKA: Jurnal Teologi Kontekstual dan Filsafat Keilahian 1, no. 2 (2016): 123-138.

${ }^{3}$ David Eko Setiawan, "Hakikat Spiritualitas Pelayan Kristus dan Implikasinya bagi Hamba Tuhan Masa Kini,” Pengarah: Jurnal Teologi Kristen 2, no. 2 (2020): 116-128. pemuridan untuk mendewasakan naradidik. ${ }^{4}$ Model pemuridan dipandang sebagai salah satu bentuk mengembangkan spiritualias naradidik. Sejalan dengan tulisan Laia, Mbeo juga dalam tulisannya memperkuat bahwa spiritualitas murid memiliki pengaruh pada sikap naradidik. ${ }^{5}$ Sikap naradidik ditentukan oleh gerakan spiritualitasnya. Spiritualitas akan mendorong naradidik berprilaku baik.

Dalam hal mendidik, guru memiliki tanggung jawab yang besar untuk mendewasakan naradidik. Berkaitan dengan tanggung jawab guru ini, Tristyanto melalui tulisannya mengemukakan bahwa guru dalam melakukan tugasnya atau mengaktulisasikan dirinya harus terlebih dahulu memahami kompetensi spiritual sebagai guru agama Kristen. ${ }^{6}$ Spiritualitas tersebut dibangun berdasarkan pada hakekat Tritunggal. Syarat penting lainnya yang ditekankan Tristyanto adalah ketika menjadi seorang guru adalah memaksimalkan kekuatan spiritual, memiliki semangat panggilan, selalu mau hidup baru dan terbuka pada karya Roh Kudus.

Kesiapan guru memang sangat dituntut dalam melakukan pendidikan spiritualitas. Hal ini juga ditekanan oleh Lase dan Hulu, dalam tulisannya lebih khusus menguraikan tentang pentingnya mengembangkan dimensi spiritualitas guru yang akan mengajar naradidik. Dua dimensi yang harus dikembangkan seorang guru adalah dimensi personal dan dimensi relasional. ${ }^{7}$ Perspektif tentang spiritualitas guru diakomodir dari pemikiran Homrighausen dan beberapa teks alkitab yang mendukung pengembangan dua dimensi spiritualitas guru.

${ }^{4}$ Oinike Laia, "Model Pemuridan yang Relevan untuk Pelayanan Pendidikan Kristen," The New Perspective in Theology and Religious Studies 1, no. 1 (2020): 1-32.

${ }^{5}$ Deni Mbeo, "Pengaruh Spiritualitas terhadap Perilaku Belajar Siswa," SESAWI: Jurnal Teologi dan Pendidikan Kristen 1, no. 2 (2020): 86-98.

${ }^{6} J u d d i$ Wahju Tristyanto, "Aktualisasi Guru Pendidikan Agama Kristen,” KERUSSO: Jurnal Teologi dan Pendidikan Agama Kristen 1, no. 1 (2017): 1-12.

${ }^{7}$ Delipiter Lase dan Etty Destinawati Hulu, "Dimensi Spiritualitas dalam Kompetensi Kepribadian Guru Pendidikan Agama Kristen," SUNDERMANN: Jurnal Ilmiah Teologi, Pendidikan, Sains, Humaniora dan Kebudayaan 13, no. 1 (2020): 13-25. 
Senada dengan tulisan ini, Janeman berbicara tentang spiritualitas guru. ${ }^{8}$ Spiritualitas guru dikaji dengan teori perkembangan kepercayaan menurut Fowler dan teori perkembangan moral menurt Kholberg. Kajian tersebut disoroti dengan penafsiran perspektif Al-kitab. Tujuan tulisan Janeman berfokus pada identifikasi tahap-tahap spiritualitas seorang guru. Dengan memenuhi tahap-tahap tersebut guru dipandang mampu menjalankan tanggung jawabnya dengan baik.

Merujuk pada telaah literatur di atas, para penulis mengulas penekanan-penekanan tentang spiritualitas pendidik, bukan bertolak dari pemikiran Parker Palmer. Palmer menguraikan pendidikan spiritualitas dengan sangat kuat menghubungkan peranan pendidik, naradidik dan materi yang dibangun di atas kebenaran Kristus. Kebenaran tersebut memiliki tiga dimensi: personal, komunal, mutualis Dengan sasaran pendidikan menyentuh naradidik secara holistic. Sehingga, signifikansi tulisan ini adalah membangun kesadaran bahwa spiritualitas merupakan hal utama dalam pendidikan kristiani. Ketika guru dan naradidik mengabaikan hal ini maka dapat dipastikan pendidikan yang terjadi dalam gereja hanya memperkaya otak atau kognisi dan terasa kering karena mengabaikan aspek afektif. Padahal keterhubungan antara aspek kognitif, afektif akan menghasilkan aspek psikomotorik yang baik. Perilaku yang baik hasil dari pendidikan yang holistik. Signifikansi ini mendukung penulis untuk menambahkan telaah terkait pendidikan spiritualitas pendidik berpijak pada pemikiran Parker Palmer. Penulis merumuskan masalah: bagaimana membangun spiritualitas pendidik? Tujuan penulisan untuk membangun dan mengembangkan spiritualitas pendidik.

${ }^{8}$ Janeman Usmany, "Spiritualitas Guru Pendidikan Agama Kristen dalam Teori Perkembangan Kepercayaan Fowler dan Teori Perkembangan Moral Kohlberg: Penafsiran Perspektif Al-Kitab," DIDAKTIKOS: Jurnal Pendidikan Agama Kristen 1, no. 2 (2018): 100-108.

\section{METODE}

Penulis menggunakan metode deskriptif argumentatif. Menurut Sugiyono, metode deskriptif adalah suatu metode yang digunakan untuk menggambarkan atau menganalisis suatu penelitian tetapi tidak digunakan untuk membuat kesimpulan yang lebih luas. ${ }^{9}$ Tujuan dari penelitian deskriptif ini adalah untuk membuat deskripsi, gambaran, atau lukisan secara sistematis, faktual dan akurat mengenai fakta-fakta, sifat-sifat serta hubungan antarfenomena yang diselidiki. Dapat dikatakan bahwa penelitian deskriptif merupakan upaya mendeskripsikan atau menganalisis suatu gejala, peristiwa yang terjadi pada masalah. Upaya ini ditindaklanjuti dengan argumen-argumen terhadap gejala atau peristiwa pada masalah terkait.

Metode deskriptif digunakan penulis dengan langkah-langkah berikut, pertama, penulis menguraikan atau mendeskripsikan makna spiritualitas. Kedua, penulis menggambarkan korelasi antara pendidikan kristiani dan spiritualitas. Ketiga, penulis menguraikan pendidikan spiritualitas menurut Parker Palmer, Keempat, penulis membuat implikasi pendidikan spiritualitas bagi pendidik dalam gereja.

\section{PEMBAHASAN}

\section{Pengertian Spiritualitas Kristen}

Spiritualitas berasal dari kata Latin spiritus yang berarti roh, jiwa, semangat. Dari kata Latin tersebut terbentuk kata Prancis l'esprit dan untuk kata bendanya adalah la spiritualite. Dari kata Inggris disebut spirituality. Dalam bahasa Indonesia disebut spiritualitas. Kalau memakai terjemahan spiritus, yaitu roh dan dikaitkan dengan Yang Transenden, maka yang dimaksudkan dengan roh adalah Roh Allah sendiri. Dengan demikian, spiritualitas dapat dirumuskan sebagai hidup menurut Roh Allah.

${ }^{9}$ Admin, "Definisi Metode Deskriptif," idtesis.com, last modified 2012, diakses Oktober 21, 2020, https://idtesis.com/metode-deskriptif/. 
Menurut pada Roh Allah berarti hidup didasarkan pada pengaruh dan bimbingan Roh Allah. ${ }^{10}$ Dengan spiritualitas, manusia berusaha merancang dan menjalankan hidupnya seperti yang Allah inginkan. ${ }^{11}$

Menurut Banawiratma, kata spiritualitas ada hubungannya dengan kata Spirit atau Roh, yaitu daya kekuatan yang menghidupkan atau menggerakkan. ${ }^{12}$ Spiritualitas dapat diartikan sebagai kekuatan atau Roh yang memberi daya tahan kepada seseorang atau kelompok untuk mempertahankan, mengembangkan, mewujudkan kehidupan. ${ }^{13}$ Dengan pemahaman bahwa spiritualitas bisa menjadi sumber kekuatan bagi seseorang atau kelompok untuk menghadapi penganiayaan, kesulitan, penindasan dan kegagalan yang dialami oleh orang atau kelompok yang sedang mewujudkan tujuan hidupnya. ${ }^{14}$ Jadi spiritualitas merupakan kesadaran dan sikap hidup manusia untuk tahan uji dan bertahan dalam mewujudkan tujuan dan pengharapan. Dalam kerangka pengertian spiritualitas di atas, maka spiritualitas bukanlah hal yang hanya berhubungan dengan kerohanian saja dan juga bukan hanya dipakai untuk menunjuk pada aktivitas manusia dalam memperoleh kesucian atau keselamatan pribadi yang bersifat rohani, serta tidak terkait dengan kehidupan manusia sehari-hari, tetapi spiritualitas justru mewujud dalam kehidupan sosial budaya, ekonomi dan politik, itulah spiritualitas sejati. ${ }^{15}$ Spiritualitas terkait erat

${ }^{10}$ Agus M. Hardjana, Religiositas, Agama Eु Spiritualitas (Yogyakarta: Kanisius, 2005), 64. Bandingkan dengan Lawrence S. Cunningham dan Keith J. Egan, Christian Sprituality: Themes from the Tradition (New Jersey: Paulist Press, 1996), 6 dan Paulinus Yan Olla, Teologi Spiritualitas: Pengantar pada Teologi Spiritual, Tema-Tema dan Strukturalisasi Pengajarannya (Yogyakarta: Kanisius, 2010), 20-29.

${ }^{11}$ A. Heuken, Spiritualitas Kristiani (Jakarta: Yayasan Cipta Loka Caraka, 2002), 12.

${ }^{12}$ J. B. Banawiratma, Spiritualitas Transformatif: Suatu Pergumulan Ekumenis (Yogyakarta: Kanisius, 1990), 57. Bandingkan dengan Olla, Teologi Spiritualitas: Pengantar pada Teologi Spiritual, Tema-Tema dan Strukturalisasi Pengajarannya, 29.

${ }^{13}$ Banawiratma, Spiritualitas Transformatif: Suatu Pergumulan Ekumenis, 57.

${ }^{14}$ Ibid.

${ }^{15}$ Ibid. dengan pergumulan dan permasalahan hidup sehari-hari. Roh, spirit itu datang dari pengalaman hidup iman orang (pribadi maupun kelompok), yaitu pengalaman akan realitas Allah, yang kemudian terejawantah dalam perilaku sehari-hari. ${ }^{16}$

Berkaitan dengan kekristenan, maka penekanan spiritualitas adalah pada perjumpaan dengan Kristus. ${ }^{17}$ Spiritualitas Kristen mengarah pada cara dimana kehidupan Kristen dipahami dan secara eksplisit mempraktekkan ketaatan yang dikembangkan untuk menopang sekaligus memperkembangkan hubungan dengan Kristus. Dengan kata lain, cara dimana setiap orang Kristen atau kelompok hendak memperdalam pengalaman mereka tentang Tuhan atau untuk mempraktekkan kehadiran Tuhan. ${ }^{18}$ Paulinus Yan Olla menjelaskan dengan cara yang berbeda, namun dengan makna yang sama, bahwa spiritualitas Kristen adalah pendasaran hidup pada Kristus, yang tampak dalam cara hidup, cara berpikir dan cara mengambil keputusan. ${ }^{19}$ Dari beberapa pengertian di atas, penulis menyimpulkan bahwa spiritualitas Kristen adalah iman atau Roh yang menggerakan atau memengaruhi kehidupan sehari-hari orang Kristen.

\section{Korelasi Spiritualitas dan Pendidikan Kristen}

Hubungan antara spiritualitas dan Pendidikan Kristiani digambarkan oleh Collen Griffith berupa tujuh diagram. ${ }^{20}$ Ia menyebutnya formasi hubungan Spiritualitas dan Pendidikan Katekese (Pendidikan Kristiani).

${ }^{16}$ Alister E. McGrath, Christian Spirituality (Massachusetts: Blackwell Publishers, 1999),1-2.

${ }^{17}$ Ibid. Lihat juga Cunningham dan Egan, Christian Sprituality: Themes from the Tradition, 7 .

${ }^{18}$ McGrath, Christian Spirituality.

${ }^{19}$ Olla, Teologi Spiritualitas: Pengantar pada Teologi Spiritual, Tema-Tema dan Strukturalisasi Pengajarannya, 29.

${ }^{20}$ Thomas H. Groome dan Harold Daly Horell, ed., Horizons 8 Hopes: The Future of Religious Education (Mahwah, New Jersey: Paulist Press, 2003), 54-56. 


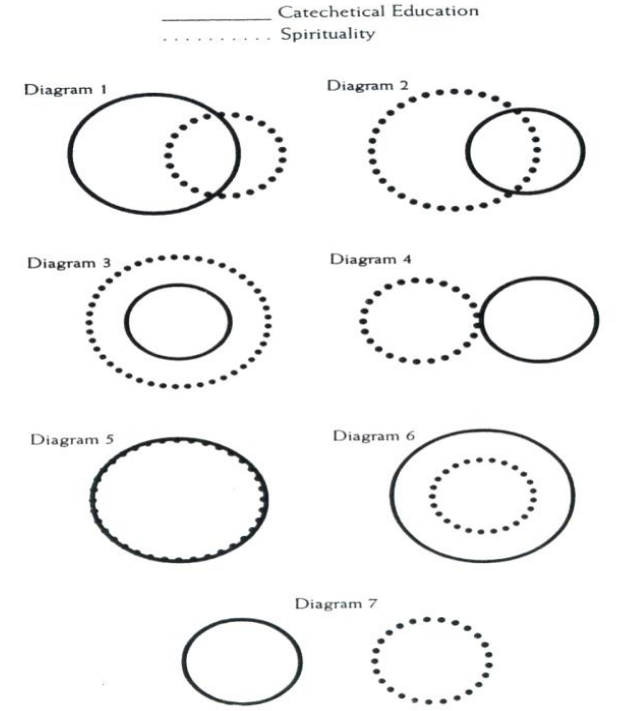

Gambar 2. Korelasi spiritualitas dan pendidikan Kristen

Setiap diagram memiliki makna yang berbedabeda. Diagram 1 menunjukkan bahwa Pendidikan Kristiani memiliki peranan yang lebih besar dibanding dengan spiritualitas. Diagram 2 menunjukkan bahwa spiritualitas berada dalam keadaan yang lebih luas dimana melebihi Pendidikan Kristiani tetapi berada dalam dimensi yang terpisah dengan baik. Diagram 3 menunjukkan bahwa Pendidikan Kristiani berada di dalam bagian spiritualitas yang lebih luas. Diagram 4 menunjukkan bahwa dua keadaan yang terpisah. Diagram 5 menunjukkan bahwa spiritualitas memiliki keadaan yang sama besarnya dengan Pendidikan Kristiani. Diagram 6 menunjukkan bahwa Pendidikan Kristiani memiliki keadaan yang lebih besar dibanding dengan spiritualitas dan spiritualitas berada di dalam Pendidikan Kristiani. Diagram 7 menunjukkan bahwa Pendidikan Kristiani dan spiritualitas berada dalam dua keadaan yang terpisah. ${ }^{21}$

Dari tujuh diagram di atas, Griffith memilih diagram ketiga. Menurutnya Pendidikan Kristiani di dalam permukaan spiritualitas yang lebih luas. ${ }^{22}$ Artinya Pendidikan Kristiani berada dalam bentangan spiritualitas. Tujuan utama proses Pendidikan Kristiani adalah demi kedewasaan spiritual. Dengan kata lain, melalui Pendidikan Kristiani, spiritualitas setiap orang bertumbuh dan berkembang menuju ke arah kedewasaan. Hal tersebut diwujudkan dalam terciptanya hubungan dengan Tuhan, kasih bagi umat manusia, dan dunia sebagai fokus utama. Oleh karena itu, maka diperlukan spiritualitas guru yang terwujud dalam proses belajar mengajar, sikap empati terhadap pengalaman hidup dan perjuangan orang lain, kepekaan terhadap kesiapan dan konteks orang lain, dan memiliki keinginan mendasar bersama naradidik untuk memperdalam pengakuan mereka akan Tuhan, sesama dan dunia. ${ }^{23}$

Penulis menyetujui gagasan Griffith di atas dengan pemahaman bahwa Pendidikan Kristiani dilakukan dalam terang spiritualitas guna tercapainya kedewasaan spiritual. Kedewasaan spiritual tidak terjadi dengan sendirinya, namun seperti yang diungkapkan Griffith bahwa tercapainya kedewasaan spiritual membutuhkan sebuah tindakan ketajaman dan juga kedalaman, discernment, langkah kontemplatif, dan sejumlah pengetahuan pribadi yang membuat kebenaran mungkin. ${ }^{24}$ Dengan demikian kedewasaan spiritual dapat berkembang melalui Pendidikan Kristiani.

Dari penjelasan korelasi spiritualitas dan Pendidikan Kristiani, maka menjadi jelas bahwa fokus Pendidikan Kristiani adalah kedewasaan spiritualitas setiap orang. Artinya, melalui Pendidikan Kristiani, diharapkan spiritualitas setiap orang dapat berkembang ke arah makin dewasa. Seperti penjelasan mengenai spiritualitas di atas, perkembangan spiritualitas yang dewasa yang dimaksudkan adalah perkembangan ke arah melakukan seperti Yesus Kristus, yaitu melakukan kehendak Allah.

\section{Teori Pendidikan Spiritualitas Menurut Parker Palmer}

Palmer menjelaskan prinsip-prinsip dasar dari pendidikan pengembangan spiritualitas yang berpusat pada Yesus Kristus. Ia menyebutnya bahwa Yesus Kristus adalah tolok ukur dari kebenaran, baik pribadi, komunal maupun mutual sehingga pendidikan mengarahkan orang untuk mengenal dan memahami Yesus Kristus,

\footnotetext{
${ }^{21}$ Ibid.

${ }^{22} \mathrm{Ibid}, 56$.
}

\footnotetext{
${ }^{23} \mathrm{Ibid}, 57-61$

${ }^{24} \mathrm{Ibid}$.
} 
kemudian mentaati Yesus Kristus sepenuhnya di dalam keseharian hidup mereka. Yesus Kristus menjadi inspirator untuk menyikapi diri dan dunia (sesama, alam semesta). Melalui Yesus Kristus, orang dipanggil untuk berelasi dengan Yesus Kristus, dirinya sendiri, sesama dan dunia. ${ }^{25}$ Jadi pengenalan akan Allah di dalam Yesus Kristus senantiasa terkait dengan dunia ini, konteks kehidupan sekarang ini dan di sini. Penjelasan mengenai teori Palmer ini, dimulai dari latar belakang pemikirannya sehingga mendorong Palmer memikirkan suatu Pendidikan yang dapat memberi ruang bagi perkembangan spiritualitas.

\section{Latar Belakang \\ Pendidikan Spiritualitas Kristen}

Ada dua hal yang menjadi dasar utama pemikiran Palmer sehingga ia memunculkan ide pentingnya Pendidikan Spiritualitas Kristen, yaitu pendidikan yang hanya menghidupkan satu sisi yang ada pada manusia, yaitu sisi kognisi, atau pikiran manusia dan pendidikan dengan sistem pengajaran kekerasan. ${ }^{26}$ Pertama dapat disebut sebagai pendidikan yang hanya menghidupkan sisi pikiran. ${ }^{27}$ Menurut Palmer, pada waktu lalu maupun masih berjalan sampai sekarang, pendidikan hanya menghidupkan kekuatan berpikir manusia. Ia menyebutnya pendidikan yang hanya menghidupkan satu mata. Pendidikan yang demikian mengakibatkan orang melihat hal-hal yang terjadi di dalam kehidupan ini (kenyataan-kenyataan yang terjadi di dunia) hanya dengan mengandalkan mata pikiran. Akibatnya, gambaran tentang dunia bukanlah gambaran tentang dunia sebagaimana dunia adanya, namun gambaran dunia berdasarkan pikiran manusia, gambaran yang tidak utuh. Gambaran dunia yang tidak utuh mengakibatkan respon yang tidak utuh pula terhadap apa yang terjadi di dunia, yaitu respon yang hanya berdasarkan pikiran. Kalau orang melihat dunia hanya dengan menggunakan sisi

\footnotetext{
${ }^{25}$ Parker J. Palmer, To Know As We Are Known: A Spirituality of Education (San Fransisco: Harper \& Row Publisher, 1983), 47-49.

${ }^{26}$ Ibid, xi.

${ }^{27}$ Ibid.
}

pikiran, maka orang melihat dunia hanya dari sisi realitas dan alasan (hubungan sebab akibat). Hal ini mengakibatkan pandangan orang bersifat dingin, kaku dan mekanistis. Dengan hanya menggunakan sisi pikiran manusia di dalam membuat gambaran tentang dunia dan meresponnya, tampak aman dan bisa diperkirakan, namun kenyataannya membangun dunia atau kehidupan hanya dari sisi pikiran saja banyak mendatangkan kekacauan di dalam dunia. ${ }^{28}$ Memandang dunia dan kejadiankejadian di dalamnya termasuk pengalaman hidup dengan hanya menggunakan satu mata atau pikiran tidaklah cukup.

Oleh karena itu, pendidikan perlu melibatkan sisi lain dari manusia, yaitu sisi hati atau perasaan ketika memandang, menggambarkan dan merespon dunia atau kehidupan. ${ }^{29}$ Dengan kata lain, perlu membuka mata yang lain juga, yaitu mata hati. Memandang dunia dari sisi hati, maka dunia yang digambarkan terasa lebih hangat karena dunia tersebut diubah oleh dunia kasih. ${ }^{30}$ Melibatkan sisi perasaan manusia (dan juga pikiran secara bersama) di dalam memandang kehidupan ini, membuat manusia memiliki gambaran yang utuh mengenai dunia, sehingga respon yang manusia berikanpun bersifat utuh, memandang dunia sebagaimana dunia adanya. Kalau manusia melihat dunia secara utuh, maka dunia menjadi utuh. Dengan demikian, tawaran pendidikan yang dimaksudkan adalah pendidikan yang menggunakan pikiran dan hati. ${ }^{31}$

Kedua, sistem pegajaran kekerasan yang selama ini terjadi dalam dunia pendidikan. Hal kedua ini muncul sebagai akibat dari hal yang pertama, yaitu pendidikan yang hanya mengandalkan pikiran belaka sehingga proses mengajar-belajar bernuansa kekerasan. Palmer menguraikan sistem pengajaran kekerasan dengan empat topik, yaitu sistem pengajaran

${ }^{28}$ Ibid, xi-xiv. Contoh: di dalam masa ilmu nuklir, kekuatan kerja pikiran manusia membuat dunia bercacat dan bahaya bahkan mematikan.

${ }^{29}$ Ibid, xi-xiv.

${ }^{30}$ Ibid.

${ }^{31}$ Ibid. 
yang mengalienasi, satu arah, persaingan, manipulator. ${ }^{32}$

Berdasarkan keprihatinan dan pemikiran di atas, maka Palmer menawarkan Pendidikan Spiritualitas Kristen. Apa, siapa dan bagaimanan Pendidikan Spiritualitas Kristen dijelaskan di bawah ini.

\section{Pengertian dan Tujuan}

Pendidikan Spiritualitas Kristen

Kata kunci untuk memahami Pendidikan Spiritualitas Kristen adalah saya, dunia, guru, naradidik, spiritualitas dan Kristen. Dalam dunia pendidikan setiap orang, diberi identitas sebagai yang mengetahui, knower dan yang diketahui adalah dunia, known. ${ }^{33}$ Yang mengetahui dan yang diketahui adalah dua hal yang saling terkait satu terhadap lainnya. Manusia hidup di dalam dunia dan dunia dalam diri manusia. Keadaan manusia mempengaruhi dunia dan keadaan dunia mempengaruhi keadaan manusia. Ada relasi antara diri manusia dengan dunia. ${ }^{34}$

Pemahaman tentang dunia tidak berhenti hanya sampai pada pemahaman konseptual berdasarkan akal pikiran saja melainkan pemahaman tentang dunia dibawa sampai kepada penghayatan sehari-hari. Keterhubungan ini hanya mungkin jika spiritualitas dikembangkan melalui Pendidikan Spiritualitas. Pendidikan Spiritualitas memungkinkan pemahaman baru, yaitu bahwa yang mengetahui dan yang diketahui adalah dua hal yang saling terkait satu terhadap lainnya. Keadaan manusia mempengaruhi dunia dan keadaan dunia memengaruhi keadaan manusia. Relasi antara manusia dengan dunia memberi pemahaman akan dunia sebagaimana dunia adanya, bersamaan dengan itu manusia pun mengetahui dirinya sebagaimana ia adanya. ${ }^{35}$ Pendidikan Spiritualitas adalah pendidikan yang mengajak orang untuk menggunakan mata pikiran dan mata hati untuk memahami dunia dengan pikiran dan perasaan, sehingga ketika manusia

\footnotetext{
${ }^{32}$ Ibid, 34-38.

${ }^{33}$ Ibid, 20-21.

${ }^{34}$ Ibid.

${ }^{35}$ Ibid, 16.
}

merespon dunia, ia meresponnya secara utuh, sebagaimana dunia adanya.

Dalam proses mengajar - belajar terdapat unsur-unsur guru, naradidik serta materi pelajaran. Guru sebagai knower, yang mengetahui dan naradidik sebagai yang diketahui, known, dan materi palajaran bisa bermacam-macam hal, seperti dunia, sejarah, tokoh tertentu, dan seterusnya. ${ }^{36}$ Pendidikan yang baik adalah yang menciptakan relasi antara guru dan naradidik, naradidik dan naradidik, serta relasi antara gurunaradidik dan materi pelajaran. Ketiga unsur tersebut saling terkait, guru merupakan bagian dari naradidik, naradidik bagian dari guru, naradidik yang satu adalah bagian dari naradidik yang lainnya sebagai satu komunitas persaudaraan dan begitupun keterkaitan dengan materi pelajaran. Pendidikan Spiritualitas adalah pendidikan yang membawa orang untuk memahami dan menerima diri sebagaimana adanya, menerima orang lain sebagaimana adanya (guru terhadap naradidik, naradidik terhadap guru, naradidik terhadap naradidik lainnya) dan memahami dunia sebagaimana adanya. ${ }^{37}$

Kalau dihubungkan dengan Pendidikan Spiritualitas Kristen, maka yang menjadi pusat pendidikan adalah Yesus Kristus. Pendidikan mengarahkan orang untuk memahami Yesus Kristus. Pemahaman tentang Yesus Kristus tidak hanya dipahami secara konseptual, namun dibawa sampai kepada penghayatan sehari-hari. Apa yang dilakukan sehari-hari didasari oleh spirit Kristen, yaitu ketaatan pada Kebenaran dan Kebenaran tersebut adalah Yesus Kristus. Melalui proses mengajar-belajar, orang diarahkan untuk taat kepada Yesus Kristus setiap saat. ${ }^{38}$

Berdasarkan latar belakang dan pengertian Pendidikan Spiritualitas Kristen, maka dapat disimpulkan tujuan Pendidikan Spiritualitas Kristen menurut Palmer adalah agar setiap orang maupun komunitas mengenal dan memahami Yesus Kristus dan menjadi taat kepadaNya dalam praktek hidup sehari-hari. Sehingga dengan demikian dalam proses mengajar - belajar pikiran 
dan hati berjalan bersama. Kalau hal tersebut dilakukan maka yang terjadi dalam proses pendidikan adalah pengajaran yang membebaskan; bukan pendidikan yang mengalienasi melainkan pendidikan yang mengaktualisasikan, bukan satu arah melainkan dua arah, bukan persaingan melainkan membangkitkan kemampuan, bukan memanipulasi melainkan mengasihi.

\section{Kebenaran dalam \\ Pendidikan Spiritualitas Kristen}

Kata Yesus kepadanya: "Akulah ... kebenaran ..." (Yoh. 14:6). Yesus Kristus mengatakan bahwa diriNya adalah kebenaran. ${ }^{39}$ Berarti Yesus Kristus adalah paradigma dari kebenaran. ${ }^{40}$ Sebagai paradigma kebenaran, maka tolok ukur dalam kehidupan di dunia ini adalah Yesus Kristus. Dengan demikian apa yang Yesus Kristus katakan dan lakukan itulah kebenaran. Maka spiritualitas Kristen bersumber pada apa yang disaksikan dalam Yohanes, bahwa Yesus Kristus adalah kebenaran. Kebenaran di dalam Yesus Kristus ini bukanlah sesuatu yang abstrak, melainkan kebenaran yang konkrit. Yesus Kristus yang berinkarnasi memberi gambaran bahwa Sabda bukanlah kata-kata, melainkan sungguh menyejarah dan menjadi daging. Tidak ada batas rohani dan jasmani, kudus dan sekuler, ini kesatuan yang saling melengkapi. ${ }^{41}$

Kebenaran memiliki dimensi personal, dimensi komunal dan mutualitas. ${ }^{42}$ Dalam memahami tiga dimensi kebenaran di atas terkait dengan pendidikan, yang menjadi kata kunci adalah relasi antara knower dan known. Agar uraian mengenai tiga dimensi menjadi fokus, maka penulis membaginya demikian, pertama jika pembahasan menyangkut kebenaran dalam artian Yesus Kristus, maka penggunaan kata knower menunjuk pada subyek yang (ingin) mengetahui, yaitu guru; naradidik. Sedangkan penggunaan kata known menunjuk pada yang (ingin) diketahui, yaitu kebenaran; Yesus

\footnotetext{
${ }^{39}$ Ibid, 47.

${ }^{40} \mathrm{Ibid}, 48$.

${ }^{41}$ Ibid, 14.

${ }^{42}$ Ibid, 47-60.
}

Kristus. ${ }^{43}$ Kedua, jika pembahasan menyangkut proses mengajar - belajar di dalam kelas, maka penggunaan kata knower menunjuk pada yang mengetahui, yaitu guru. ${ }^{44}$ Sedangkan penggunaan kata known menunjuk pada yang diketahui, yaitu naradidik. Ketiga, jika pembahasan menyangkut guru, naradidik dan materi pelajaran, maka penggunaan kata knower menunjuk pada yang mengetahui, yaitu guru; naradidik. Sedangkan penggunaan known menunjuk pada yang diketahui, yaitu materi pelajaran. Namun demikian, dalam uraian ketiga dimensi kebenaran di bawah ini, penggunaan kata knower dan known lebih kepada penjelasan pertama. Sedangkan penjelasan kedua dan ketiga dipakai dalam proses mengajar - belajar.

\section{Proses Mengajar dan Belajar yang Terjadi dalam Pendidikan Spiritualitas Kristen}

Arah Pendidikan Kristiani yang dipraktekkan di gereja maupun di sekolah-sekolah, baik naradidik, guru, maupun materi pelajaran haruslah mengacu pada Yesus sebagai pusat/kebenaran. Guru perlu menghubungkan dirinya secara pribadi dengan Yesus Kristus. Naradidik diarahkan agar memiliki hubungan secara pribadi dengan Yesus Kristus. Materi pelajaran adalah materi yang membawa orang untuk memahami dan memiliki hubungan dengan Yesus. Berikut akan dijelaskan mengenai unsur-unsur dalam proses mengajar - belajar, yaitu pendidik, murid dan materi pelajaran.

\section{Peran Pendidik. ${ }^{45}$}

Dalam Pendidikan Spiritualitas, guru adalah orang yang memiliki peran paling utama agar tercipta ruang, baik bagi dirinya, naradidik maupun materi pelajaran yang di dalamnya

${ }^{43}$ Penggunaan kata known yang menunjuk pada kebenaran atau Tuhan Yesus, sebetulnya tidak pernah lepas dari sesama dan dunia, oleh karena pengenalan akan Yesus dan relasi dengan Yesus yang adalah kebenaran itu sendiri selalu terkait dengan sesama dan dunia.

${ }^{44}$ Palmer tidak menentukan tempat mengajarbelajar.

${ }^{45}$ Palmer, To Know As We Are Known: A Spirituality of Education, 69-105. 
ketaatan pada kebenaran dipraktekkan bersama. Palmer mengatakan, "To teach is create a space in which obedience to Truth is practiced." ${ }^{46}$ Agar pandangan di atas dapat semakin jelas, maka dimulai dengan pengertian mengenai to "create a space." ${ }^{47}$ Mengajar adalah menciptakan ruang yang tenang, hening. Keheningan adalah suasana yang penting bagi pertumbuhan spiritualitas. Ruang yang dimaksudkan adalah ruang dalam hati dan pikiran, yang mana orang bebas untuk masuk ke kedalaman suara batin. Di dalam ruang ketenangan hati dan pikiran tersebut menolong orang menetapkan kebenaran. Dalam hal ini adalah mengkonkritkan apa yang dimaksudkan dengan dasar untuk menyelamatkan. ${ }^{48}$ Pendidikan yang memberi ruang bagi perkembangan spiritualitas adalah Pendidikan yang semakin banyak memberi ruang bagi keheningan. Ruang yang terbentuk dapat menenun ikatan kesetiaan yang di dalamnya orang dapat mencari kebenaran dan kebenaran mencari dirinya. ${ }^{49}$

Pengertian lain menciptakan ruang bagi perkembangan spritualitas atau penemuan akan kebenaran melalui keheningan adalah membuka ruang agar ide-ide dan perasaan (pikiran dan hati) muncul bersama. Pendidikan yang memberi ruang bagi penemuan akan kebenaran yang sesungguhnya adalah pendidikan yang memberi keseimbangan antara pikiran dan perasaan. Pikiran dan perasaan berjalan bersama. $^{50}$ Dalam ruang tersebut, guru dan naradidik berusaha untuk saling mendengarkan dan memberi respon sehingga kebenaran diberlakukan dalam proses belajar-mengajar. Untuk mempraktikkan ketaatan kepada kebenaran di dalam kelas (dalam proses mengajar dan belajar) guru dan naradidik perlu mulai dengan pemikiran dan tindakan yang tidak memisahkan antara kelas dan dunia. ${ }^{51}$ Sehubungan dengan pengertian di atas, mau menyadarkan orang bahwa pada saat proses mengajar-belajar berlangsung, itulah realitas dari

\footnotetext{
${ }^{46} \mathrm{Ibid}, 69$.

${ }^{47}$ Ibid.

${ }^{48}$ Ibid.

${ }^{49}$ Ibid., 69-70.

${ }^{50}$ Ibid, $17-18$.

${ }^{51}$ Ibid, 88-89.
}

orang yang sedang berada dalam proses mengajar-belajar tersebut. Realitas tidak berada di luar proses mengajar-belajar, atau berada pada waktu yang akan datang. Suasana kelas dan dunia, adalah dua hal yang saling terhubung, tidak terpisahkan. ${ }^{52}$

Faktor pendukung lainnya, yang dibutuhkan agar terjadi sikap yang mempraktekkan ketaatan kepada kebenaran yaitu suasana di dalam kelas. Untuk itu, Palmer menawarkan proses mengajarbelajar dalam suasana pertemanan, persaudaraan dan kekeluargaan. Guru yang adalah sosok yang menguasai materi pelajaran memperkenalkannya kepada naradidik bagaikan seorang yang memperkenalkannya pada seorang sahabat. ${ }^{53}$ Dalam suasana pertemanan tersebut, guru menghargai para naradidik sebagai sahabat yang berpotensi untuk membangun relasi dengan materi pelajaran dengan caranya sendiri. ${ }^{54}$

Pembentukan spiritualitas guru menjadi sangat penting di dalam proses mengajar dan belajar yang berujung pada pembentukkan spiritualitas dalam diri naradidik. Disiplin pembentukan spiritualitas guru akan melatih atau memperkuat kapasitas, baik guru maupun naradidik di dalam mempraktekkan ketaatan kepada kebenaran. Artinya dimulai dari guru. Guru memperhatikan aspek afektif dirinya dan murid sehingga transformasi pengajaran dari guru ke murid dimulai dari hati sang guru yang penuh kasih, yang telah terlebih dahulu mengalami transformasi. Dengan kata lain, transformasi pengajaran harus dimulai dari hati sang guru yang telah tertransformasi. Hanya dalam hati yang senantiasa mencari kebenaran dan berani diubah oleh kebenaran, teknik dan strategi pendidikan baru akan terbentuk dengan kokoh kuat. Bila seseorang memperbaharui sistem pendidikan dan jalannya untuk mengenal dunia ini, ia harus membuka hati pada cinta dan kebenaran yang telah ada sejak sediakala. Seseorang itu harus mendisiplinkan diri untuk membiarkan cinta dan kebenaran untuk membentuk hatinya dan mendisiplin keberanian untuk senantiasa terbuka pada sistem pendidikan yang baru supaya murid-murid

\footnotetext{
${ }^{52}$ Ibid, 88-89.

${ }^{53}$ Ibid, 103-105.

${ }^{54}$ Ibid.
} 
diubahkan, sekolah diubahkan dan dunia dimana manusia berada diubahkan juga. Dari situ akan muncul buah dari praktek spiritualitas sang guru. Buah dari praktik spiritualitas guru adalah kemanusiaan dan iman. Aspek kemanusian yang memungkinkan guru untuk masuk dalam hubungan dengan murid dan materi pelajaran. Iman, yang memampukan guru untuk berbicara kebenaran yang mereka yakini. ${ }^{55}$

\section{Peran Naradidik}

Naradidik adalah subyek yang terhubung dengan guru, materi pelajaran, sesama murid dalam usaha mencari kebenaran. Naradidik adalah subyek yang menjadi perhatian bagi praktek ketaatan kepada kebenaran. Naradidik adalah subyek yang menjadi sasaran pendidikan agar terbentuk spiritualitas di dalam dirinya. Naradidik adalah subyek yang menjadi sasaran pendidikan yang membuat keseimbangan antara pikiran dan hati. ${ }^{56}$

Dalam proses mengajar belajar, naradidik bersama guru menciptakan suasana persaudaraan. Pengajarannya yang didapatnya ditindak-lanjut dengan mulai mengaktualisasikan pengajaran ke dalam hidup sehari-hari sekarang ini demi masa depan yang lebih baik. Naradidik bersikap terbuka baik kepada guru dan temantemannya dengan jalan rela belajar dari guru, membagikan pengalamannya kepada guru dan teman-temannya karena pengalamannya dapat menjadi sumber pemahaman. Naradidik memberi kesempatan kepada guru untuk menjadi gurunya.

\section{Materi Pelajaran}

Menurut Palmer, dalam Pendidikan Spiritualitas Kristen, materi pelajaran berpusat pada Yesus Kristus. ${ }^{57}$ Materi pelajaran adalah materi pelajaran yang isinya memungkinkan seseorang memiliki hubungan pribadi dengan Yesus Kristus, sebagai kebenaran. Isi materi

\footnotetext{
${ }^{55}$ Ibid, xi-xiv.

${ }^{56} \mathrm{Ibid}, 47-105$.

${ }^{57} \mathrm{Ibid}, 65$. Pemahaman di atas bukan hanya di dalam halaman tersebut saja, namun terdapat di dalam secara keseluruhan buku Palmer ini.
}

pelajaran adalah materi pelajaran yang memungkinkan orang mendengarkan panggilan Yesus Kristus dan meresponNya. Panggilan Yesus tersebut adalah panggilan karena kasih dan panggilan untuk mengasihi. Artinya dalam pendidikan, tindakan atau usaha untuk mengetahui adalah suatu tindakan kasih. Suatu tindakan untuk memasuki dan merangkul realitas lain, tindakan untuk membiarkan yang lain untuk memasuki dan merangkul kita sendiri. ${ }^{58}$

Dengan demikian, yang ditekankan dalam materi pelajaran, bukan hanya memberi ruang bagi hubungan dengan Yesus, sebagai kebenaran, melainkan juga memberi ruang bagi hubungan dengan sesama dan dunia melalui tindakan kasih, sehingga pengetahuan yang muncul dari kasih akan berimplikasi pada diri seseorang di dalam jaringan kehidupan. Yang mengetahui (guru dan naradidik) dan yang diketahui atau pengetahuan (kebenaran) dihubungkan dalam suatu perasaan yang dekat-mendalam. Di antara guru dan naradidik, naradidik dan naradidik memiliki keterjalinan. Ketika terjadi keterjalinan antara Yesus dan guru maupun nara didik dan di antara naradidik melalui materi pelajaran yang berpusat pada Yesus itu, bukan hanya keterjalinan biasa, namun keterjalinan tersebut merupakan perbaikan kembali dari hubungan yang rusak. Tujuan pengetahuan yang didasari oleh kasih adalah menciptakan penyatuan kembali dan pembangunan kembali diri sendiri dan dunia yang sebelumnya rusak dan terpecah. ${ }^{59}$ Dalam perkembangannya hubungan pribadi dengan Yesus Kristus tersebut akhirnya mewujud dalam karakter seperti Yesus. Perkembangan spiritualitas $\mathrm{di}$ atas semakin dimungkinkan jika orang juga melakukan disiplin spirtualitas.

Palmer mengusulkan tiga disiplin spiritualitas untuk membantu perkembangan spiritualitas dalam diri orang. Disiplin tersebut adalah belajar dari teks-teks suci; doa dan kontemplasi; hidup bersama dalam komunitas sendiri. ${ }^{60}$ Pertama, Teks. Melalui belajar dari teks suci, orang dibawa kembali kepada kedalaman

\footnotetext{
${ }^{58} \mathrm{Ibid}, 6-8$.

${ }^{59}$ Ibid, 8-9.

${ }^{60} \mathrm{Ibid}, 17-19$.
} 
spiritualitas mereka. Artinya dengan membaca teks suci, orang masuk ke dalam perjalanan spiritual. Dengan masuk ke dalam perjalanan spiritual orang dewasa diingatkan kembali kepada kebenaran-kebenaran yang belum jelas, dan sekalian mencari dan menemukan kebenaran yang sesungguhnya, yaitu apa yang sesuai dengan yang teks maksudkan. ${ }^{61}$ Dari membaca teks, orang dibawa untuk melihat apa yang terjadi di waktu lalu, artinya apa kebenaran yang terdapat di dalam teks, sekaligus sebagai cermin untuk melihat apa kebenaran-kebenaran sebelumnya yang ia atau orang yang membaca teks tersebut, sehingga melalui perjalanan spiritual melalui mempelajari teks suci tersebut, orang bisa dibawa sampai kepada reformasi hati dan pikiran oleh karena ada klarifikasi dan pembaharuan. Kedua, doa dan kontemplasi. Doa dan kontemplasi membawa orang untuk menemukan kasih yang melampaui angan-angan; membentuk orang untuk menerima kasih sejak di dalam hati sebagai perjalanan spiritual. ${ }^{62}$ Ketiga, hidup bersama dengan komunitas spiritual. Komunitas adalah disiplin saling menyemangati dan saling menguji; membuat orang penuh harapan dan jujur tentang kasih yang dicari. ${ }^{63}$

\section{Implikasi bagi Pelayanan Pendidikan Spiritulitas}

Implikasi teori Palmer bagi pendidikan dalam gereja dapat dijelaskan menggunakan gambar berikut,

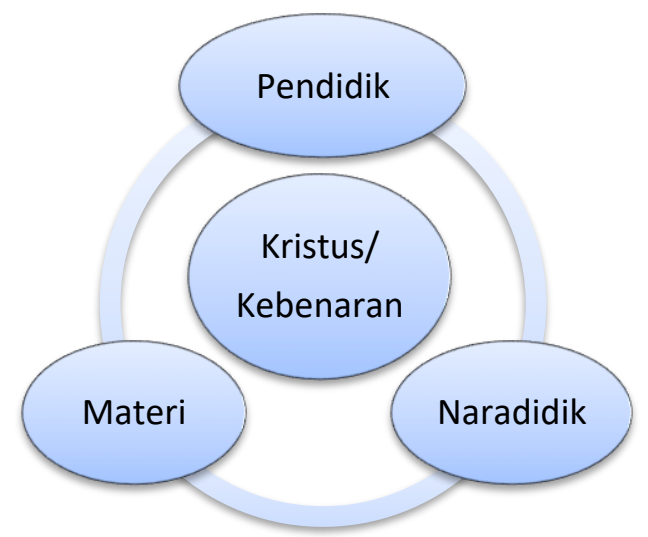

Gambar 2. Pendidikan Spiritualitas Kristen dalam gereja

\footnotetext{
${ }^{61}$ Ibid.

${ }^{62} \mathrm{Ibid}$.

${ }^{63} \mathrm{Ibid}$.
}

Penulis menggunakan gambar untuk menegaskan unsur-unsur penting dalam pendidikan spiritualitas Kristen. Ketiga unsur penting yakni: guru atau pendidik, murid atau naradidik, dan materi. Ketiga unsur tersebut saling terjalin atau saling terhubung dan digerakan oleh spiritualitas Kristen atau kebenaran.

Pendidikan spiritualitas yang dilakukan di gereja mensyaratkan kesiapan unsur-unsur tersebut. Pertama-tama guru dalam hal ini yang berperan sebagai pendidik dalam gereja perlu memperhatikan kesiapan spiritualitasnya, merawat dan mengembangkan spiritualitas pribadi. Perawatan spiritualitas guru akan berdampak dalam relasi dengan nara didik dan materi yang digunakan dalam proses mengajarbelajar. Naradidikpun turut mengembangkan spiritualitas berdasarkan kebenaran, sehingga dapat dengan terbuka dan bekerjasama dengan pendidik dalam proses mengajar-belajar. Berikut, terkait materi, dalam persiapannya materi yang akan disajikan memiliki ruang dan muatan relasi dengan dengan Tuhan, sesama dan alam.

Ketika guru atau pendidik memiliki spiritualitas yang baik, maka spiritualitas itu akan mempengaruhi gaya/proses belajar. Proses belajar yang membebaskan, memanusiakan, hangat dan saling menghargai. Spirit ituah yang akan tertular ke naradidik karena naradidik melihat teladan dari guru. Dengan demikian maka naradidik pun dengan mudah menghidupi dan mengembangkan spiritualitasnya. Spritualitas yang lahir dari proses pendidikan ini tentunya akan berdampak dalam kehidupan sehari-hari.

\section{KESIMPULAN}

Spritualitas adalah daya yang menggerakan seseorang atau kelompok dalam kehidupan sehari-hari. Buah dari kehidupan sehari-hari sesorang ditentukan oleh spiritualitasnya. Spiritualitas Kristen berdasar pada kebenaran (Yesus Kristus). Berdasarkan kebenaran tersebutlah pendidikan spiritualitas terjadi atau dilakukan dalam gereja. Pendidikan Kristen dalam gereja memiliki korelasi dengan 
spiritualitas. Pendidikan Kristen ada dalam bentangan spiritualitas. Spiritualitas Kristen menjadi dasar dalam proses atau pelaksanaan pendidikan Kristen dalam gereja. Teori pendidikan spiritualitas menurut Parker menjadi rujukan utama dalam tulisan ini. Bagi Palmer, pendidikan spiritualitas Kristen menghubungkan "yang mengetahui' (guru dan naradidik) dan "yang diketahui/pengetahuan”(kebenaran).

Pendidikan spiritualitas dapat dimulai dari pengembangan spiritualitas guru atau pendidik. Spiritualitas guru sangat mempengaruhi kualitas proses mengajar-belajar dan relasi bersama naradidik. Pendidikan spiritualitas yang sengaja dilakukan ini akan mempengaruhi prilaku sehari-hari. Semua orang yang belajar spiritualitas akan menggunakan mata pikiran dan mata hati untuk memahami dunia dengan pikiran dan perasaan, sehingga ketika manusia merespon dunia, ia meresponnya secara utuh, sebagaimana dunia adanya.

\section{KEPUSTAKAAN}

Admin. "Definisi Metode Deskriptif." idtesis.com. Last modified 2012. Diakses Oktober 21, 2020. https://idtesis.com/metodedeskriptif/.

Banawiratma, J. B. Spiritualitas Transformatif: Suatu Pergumulan Ekumenis. Yogyakarta: Kanisius, 1990.

Cunningham, Lawrence S., dan Keith J. Egan. Christian Sprituality: Themes from the Tradition. New Jersey: Paulist Press, 1996.

Groome, Thomas H., dan Harold Daly Horell, ed. Horizons $\mathcal{B}$ Hopes: The Future of Religious Education. Mahwah, New Jersey: Paulist Press, 2003.

Hardjana, Agus M. Religiositas, Agama Spiritualitas. Yogyakarta: Kanisius, 2005.

Heuken, A. Spiritualitas Kristiani. Jakarta: Yayasan Cipta Loka Caraka, 2002.

Laia, Oinike. "Model Pemuridan yang Relevan untuk Pelayanan Pendidikan Kristen.” The New Perspective in Theology and Religious Studies 1, no. 1 (2020): 1-32.

Lase, Delipiter, dan Etty Destinawati Hulu.
"Dimensi Spiritualitas dalam Kompetensi Kepribadian Guru Pendidikan Agama Kristen." SUNDERMANN: Jurnal Ilmiah Teologi, Pendidikan, Sains, Humaniora dan Kebudayaan 13, no. 1 (2020): 13-25.

Mbeo, Deni. "Pengaruh Spiritualitas terhadap Perilaku Belajar Siswa." SESAWI: Jurnal Teologi dan Pendidikan Kristen 1, no. 2 (2020): 86-98.

McGrath, Alister E. Christian Spirituality. Massachusetts: Blackwell Publishers, 1999.

Olla, Paulinus Yan. Teologi Spiritualitas: Pengantar pada Teologi Spiritual, Tema-Tema dan Strukturalisasi Pengajarannya. Yogyakarta: Kanisius, 2010.

Palmer, Parker J. To Know As We Are Known: A Spirituality of Education. San Fransisco: Harper \& Row Publisher, 1983.

Setiawan, David Eko. "Hakikat Spiritualitas Pelayan Kristus dan Implikasinya bagi Hamba Tuhan Masa Kini.” Pengarah: Jurnal Teologi Kristen 2, no. 2 (2020): 116-128.

Siahaan, Daniel Syafaat. "Pendidikan Kristiani sebagai Instrumen Penyadaran Pentingnya Pertumbuhan Spiritualitas dalam Konteks Budaya Populer." GEMA TEOLOGIKA: Jurnal Teologi Kontekstual dan Filsafat Keilahian 1, no. 2 (2016): 123-138.

Tristyanto, Juddi Wahju. "Aktualisasi Guru Pendidikan Agama Kristen.” KERUSSO: Jurnal Teologi dan Pendidikan Agama Kristen 1, no. 1 (2017): 1-12.

Usmany, Janeman. "Spiritualitas Guru Pendidikan Agama Kristen dalam Teori Perkembangan Kepercayaan Fowler dan Teori Perkembangan Moral Kohlberg: Penafsiran Perspektif Al-Kitab.” DIDAKTIKOS: Jurnal Pendidikan Agama Kristen 1, no. 2 (2018): 100-108.

Wilson, Bawamenewi. "Spiritualitas Seorang Pelayan Tuhan.” ERESI: Jurnal Teologi dan Pendidikan Agama Kristen 1, no. 1 (2020): 61-66. 